\title{
A Developmentally Significant Antigen in the Surface of Frog Embryo Cells ${ }^{1}$
}

\author{
George W. Nace \\ Department of Zoology, Universily of Michigan, \\ Ann Arbor, Michigan
}

Accepted October 29, 1962

INTRODUCTION

Weiss has repeatedly emphasized the developmental significance of specific reactions of macromolecules in the surface of cells with components in the cellular environment (Weiss, 1962, and earlier papers). Few of these specific macromolecules, however, have been identified.

In an earlier report, Nace and Inoue (1957) showed that, when incorporated into the culture medium, rabbit antisera directed against Rana pipiens neurula antigens (Shumway stages 14 and 15) cytolyzed the cells in $92 \%$ of hanging drop cultures of dorsal trunk tissues (Fig. 1B). After absorption of the antisera with the water-soluble component of washed yolk platelets (pseudoglobulin) the cultures were not cytolyzed. Instead, static cultures were obtained in $55 \%$ of the cases, and epidermal or mesenchymal differentiations were obtained in $45 \%$ of the cultures (Fig. 1C). This contrasted with the cultures in normal medium which were dominated by neural crest derivatives and were free of epidermal cells in $95 \%$ of the cases. It was also shown that absorption of the antisera with the water-insoluble component of the yolk platelets (vitellin) was not effective in removing the cytolytic activity of these antisera.

The reason for using these yolk components as absorbing reagents was not revealed in our earlier report, but was derived from the comparison of normal and cytolyzed cultures. Figure 1A shows that yolk platelets are the major cytoplasmic structures visible in the cells at 24 hours of culture in normal medium. Figure $1 \mathrm{~B}$ shows that the yolk platelets are missing from the precytolytic cells found in cultures

${ }^{1}$ This investigation was supported by research grant RG 5409 from the National Institutes of Health, United States Public Health Service. 
containing the unabsorbed antineurula sera, and only the ghosts of yolk platelets are found in the debris resulting from the cytolysis of

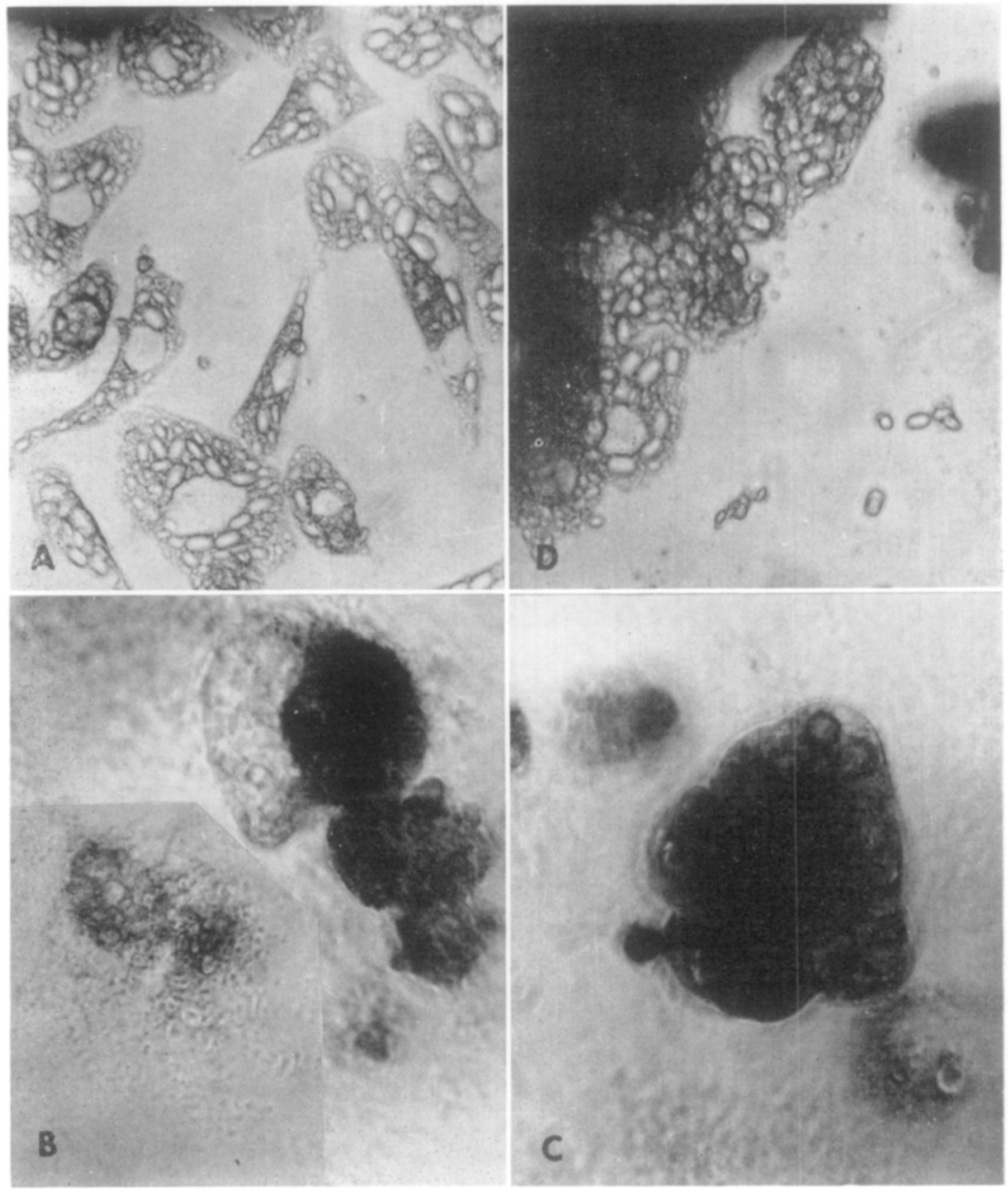

FIG. 1. Frog neurula tissue cultures. (A) Niu-Twitty medium, 24 hours, normal. (B) Medium containing antineurula globulin, 24 hours, precytolytic cells at upper right, cytolyzed cells at lower left. (C) Medium containing antineurula globulin absorbed with yolk pseudoglobulin, 4 days, shows undifferentiated and epidermal cells. (D) Medium containing antineurula globulin absorbed with neurula supernatant. It contained no antibodies; 24 hours, normal. Note the serological precipitate in (B) and (C) and its absence from (A) and (D). Uniform magnification. 
these cells. It was this observations which led us to helieve that yolk proteins, either pseudoglobulin or vitellin, might be involved in the cytolytic system. The fate of cultures in absorbed antisera and the accompanying agar diffusion tests (Nace and Inoue, 1957) confirmed this view by demonstrating that yolk pseudoglobulin and its antibody constituted the cytolytic system.

Two hypotheses were suggested by these data. First, the antibodies directed against pseudoglobulin pass into the cells, prematurely lyse the yolk platelets and lead to cytolysis of the cells through the resulting cellular derangement. Or, second, the antibodies combine with cell membrane proteins which possess the antigenic specificity of yolk pseudoglobulin. This leads to precytolytic changes in the cell membrane and secondarily to both the lysis of the platelets and the cytolysis of the cells.

The first hypothesis requires that yolk platelets be directly susceptible to lysis by the antisera. The second hypothesis does not require this direct susceptibility. It was the object of the experiment reported here to determine the susceptibility of yolk platelets to the cytolytic antisera and to other related antisera.

\section{MATERIALS AND METHODS}

Mature ovarian eggs of Rana pipiens from Vermont were homogenized, and the yolk platelets were collected by low speed centrifugation. After repeated washing the platelets were suspended in 10 volumes of c'alcium-free amphibian balanced salt solution.

Both whole sera and globulin fractions of normal rabbit sera and the antisera were tested. The latter included antisera directed against supernatants of mature ovarian oocytes, ncurulae, and adult kidncy prepared as described elsewhere (Nace and Inoue, 1957; Nace et al., 1961). Antiserum directed against frog oocyte lysozyme was also tested because of the localization of this water-soluble antigen in yolk platelets (Nace, 1962).

The tests were conducted in depression slides, where yolk suspension was mixed with each of the antisera and the normal sera at three dilutions corresponding to the serum concentrations used in the cultures. Results were observed microscopically over a 10 -hour period of incubation at room temperature. These test suspensions were compared with similar suspensions in which the platelets were lysed by $10 \% \mathrm{NaCl}$. 


\section{RESULTS AND CONCLUSIONS}

Yolk platelets were not lysed by any of the antisera tested, including antisera which cytolyzed the cultured cells.

These results indicate that the lysis of in situ yolk platelets in cultures (Fig. 1B) was not produced by the passage of antibody into the cells as suggested by the first hypothesis. Rather, it seems likely the platelets were destroyed by a mechanism involving the combination of the antibody with antigens in the cell membranes, as suggested by the second hypothesis.

Although the details of this mechanism cannot be specified, it must be attributed to a macromolecular entity or entities which possesses the antigenic properties of pseudoglobulin (Nace and Inoue, 1957). Antibodies present in the complex antineurula sera after removal of the antibodies to pseudoglobulin were capable of altering the direction of differentiation in the cultures from a neural to an epidermal fate, but were not capable of cytolyzing the cultures. This suggests a key role for pseudoglobulin in at least maintaining the integrity of these neurula cells.

These observations clearly correspond with expectations based on the views expressed by Weiss (1962) concerning the role of macromolecules in cell surfaces. It therefore gives me pleasure to add this datum to this volume dedicated to the honor of Dr. Paul Weiss, who has contributed so much to us as individuals and to all who have attempted to answer some of the riddles of the developing organism.

\section{SUMMARY}

Data demonstrating the role of yolk pseudoglobulin in maintaining the integrity of frog neurula cells in hanging drop cultures wcre rccalled. Evidence was presented to demonstrate that the cytolysis of these cultured cells by antineurula sera was preceded by in situ lysis of yolk platelets. It was shown that washed yolk platelets directly exposed to the cytolytic antisera as well as to other antisera were not lysed. This led to the conclusion that the cytolysis of the cultured cells must be attributed to the action of the antisera on cell membrane antigens with pseudoglobulin specificity rather than to the passage of antibody into the cells.

\section{REFERENCES}

NAce, G. W. (1962). Discussion. In "Symposium on Specificity of Cell Differentiation and Interaction.” J. Cellular Comp. Physiol. 6, Suppl. 1, 61. 
Nace, G. W., and Inoue, K. (1957). Cytolysis versus differentiation in antineurula serum. Science 126, 259-261.

Nace, G. W., Suyama, T., and Smith, N. (1961). The development of special proteins. In "Germ Cells and Earliest Stages of Development. Symposium of I.I.E.-Pallanza, 1960" (S. Ranzi, ed.), pp. 564-603. Istituto Lombardo, Milan, Italy.

WeIss, P. (1962). From cell to molecule. In "The Molecular Control of Cellular Activity" (J. M. Allen, ed.), pp. 1-72. McGraw-Hill, New York. 